\title{
Visual Novel Interaktif Cerita Fabel Kelinci dan Kura-Kura Pada Smartphone Berbasis Android Dengan Memanfaatkan Framework Fungus
}

\author{
Muhammad Irfan Serfia \\ Program Studi Teknik Informatika \\ Institut Informatika Indonesia \\ muh.irfanserfia@gmail.com
}

\author{
Timothy John Pattiasina \\ Program Studi Sistem Informasi \\ Institut Informatika Indonesia \\ temmy@ikado.ac.id
}

\author{
Edwin Meinardi Trianto \\ Program Studi Manajemen \\ Informatika \\ Institut Informatika Indonesia \\ edwin@ikado.ac.id
}

\begin{abstract}
Abstrak - Ilmu pengetahuan dan teknologi berkembang dengan pesat, dimana media pembelajaran dengan menggunakan buku mulai ditinggalkan dan beralih menggunakan bentuk digital. Untuk itu, dalam penelitian ini dirancang dan dibuat aplikasi berjudul "Vino: Kelinci Dan Kura-Kura" yang bertujuan untuk menarik minat baca anak usia 4 sampai 7 tahun. Aplikasi visual novel interaktif ini mengangkat tema cerita fabel yang dikemas dalam bentuk interaktif pada smartphone berbasis Android. Aplikasi ini dikembangkan dengan Unity 3D yang memanfaatkan Framework Fungus. Beberapa fitur dalam aplikasi ini adalah fitur touch dan drag yang membuat aplikasi menjadi lebih menarik untuk dimainkan. Selain itu, terdapat interaksi dalam setiap scene yang digunakan pengguna untuk menentukan alur cerita. Berdasarkan hasil pengujian white box testing menggunakan metode basis path, aplikasi berhasil berjalan dengan baik. Selanjutnya dilakukan uji coba usability testing menggunakan metode problem discovery. Dari hasil uji coba tersebut, aplikasi "Vino: Kelinci Dan Kura-Kura" dapat menarik minat baca anak usia 4 sampai 7 tahun. Hal ini dapat dibuktikan dari 10 responden yang memainkan aplikasi berulang kali untuk mencari tahu 3 jalan cerita yang berbeda, yaitu normal ending, bad ending, dan perfect ending.
\end{abstract}

Kata Kunci: Cerita Fabel, Framework Fungus, Usability Testing, Visual Novel Interaktif, White Box Testing

\section{PENDAHULUAN}

Perkembangan ilmu pengetahuan dan teknologi tidak pernah mengalami kemunduran, media buku yang digunakan untuk pembelajaran kini ditinggalkan, digantikan dengan media komputer atau smartphone dan internet. Namun, dengan adanya smartphone membuat media pembelajaran menjadi mudah untuk dijangkau. Salah satu cara untuk menarik minat baca anak-anak yaitu dengan memanfaatkan media pembelajaran berbasis teknologi dalam bentuk visual novel interaktif, yang mengangkat unsur cerita fabel.
Cerita fabel sendiri adalah kisah yang menceritakan kehidupan hewan yang memiliki sifat menyerupai manusia. Fabel adalah cerita fiksi atau khayalan belaka. Cerita fabel juga sering disebut cerita moral karena mengandung pesan yang berkaitan dengan moral. Berkembangnya teknologi informasi memberikan dampak bagi cerita fabel itu sendiri. Cerita fabel dipublikasikan melalui berbagai media, antara lain adalah buku, parodi dan film. Media lain yang dapat digunakan selain buku adalah visual novel. Sebuah visual novel dapat digunakan sebagai alternatif pembelajaran dari suatu hal, atau visual novel bisa menimbulkan minat untuk mengetahui sesuatu tema yang diangkat pada visual novel. Visual novel memiliki kelebihan tersendiri dalam menyampaikan pesan-pesan cerita dalam bentuk audio visual dan dapat menjadi media penyampaian yang mudah dipahami.

\section{METODOLOGI PENELITIAN}

\section{A. Media Pembelajaran}

Media pembelajaran secara umum adalah alat bantu proses belajar mengajar. Segala sesuatu yang dapat dipergunakan untuk merangsang pikiran, perasaan, perhatian dan kemampuan atau keterampilan pelajar sehingga dapat mendorong terjadinya proses belajar. Batasan ini cukup luas dan mendalam mencakup pengertian sumber, lingkungan, manusia dan metode yang dimanfaatkan untuk tujuan pembelajaran atau pelatihan [1].

B. Visual Novel Interaktif

Novel visual atau visual novel atau yang terkadang disebut sound novel adalah sebuah jenis permainan interaksi fiksi yang dapat dimainkan di PC (Personal Computer) dan sebagian disediakan untuk berbagai perangkat permainan lain seperti PSP (Play Station Portable), NitendoDS, PS (Play Station), hingga smartphone. Game ini berbasis fiksi interaktif yang menampilkan cerita novel dalam bentuk gambar-gambar statis biasanya digambar dengan gaya manga atau model komik Jepang, dan dilengkapi dengan kotak percakapan untuk menyampaikan narasi dan ucapan setiap 
karakter, dan terkadang setiap karakter memiliki sound effect sehingga setiap karakter yang ada dalam visual novel seolah hidup dan dapat berbicara [2].

\section{Cerita Fabel}

Cerita fabel adalah cerita yang isinya menggambarkan sifat, kelakuan, watak manusia yang pelakunya dimainkan oleh sekumpulan para hewan. Untuk lebih jelasnya fabel diartikan sebagai kehidupan hewan yang perilakunya mirip seperti manusia pada umumnya [3].

\section{Storyboard}

Storyboard adalah suatu sketsa gambar yang disusun secara berurutan sesuai naskah cerita. Dengan storyboard maka pembuat cerita dapat menyampaikan ide cerita secara lebih mudah kepada orang lain, karena dengan storyboard maka pembuat cerita dapat membuat seseorang membayangkan suatu cerita mengikuti gambar-gambar yang sudah tersaji, sehingga dapat menghasilkan persepsi yang sama dengan ide cerita yang di buat. Storyboard juga dapat di artikan sebagai naskah yang di sajikan dalam bentuk sketsa gambar yang berurutan, berguna untuk memudahkan pembuatan alur cerita maupun pengambilan gambar [4].

\section{E. Bahasa Pemrograman $C \#$}

Bahasa pemrograman $\mathrm{C} \#$ bisa jadi sangat rumit pada awalnya, namun kenyataannya, ada dua bagian dasar yang membentuk fondasinya, bagian itu adalah variabel dan metode. Bahasa pemrograman sederhana yang digunakan untuk tujuan umum, dalam artian bahasa pemrograman ini dapat digunakan untuk berbagai fungsi misalnya untuk pemrograman server-side pada website, membangun aplikasi desktop ataupun mobile, pemrograman game dan sebagainya $[5]$.

\section{F. Unity $3 D$}

Unity $3 D$ adalah perangkat lunak pembuat game 3 Dimensi. Fitur Unity $3 D$ telah cukup efektif jika dibanding dengan memakai program framework. Program framework membuat para pengembang game memulai dari awal untuk membuat sistem-sistem yang akan digunakan pada game. Terutama game 3 Dimensi yang mempunyai sistem framework yang kompleks [6].

\section{G. Fungus}

Framework Fungus yang digunakan untuk membantu membuat alur cerita yang sesuai dengan keinginan pengguna dan terdapat efek visual yang dapat menggambarkan suasana saat memainkan visual novel yang dibuat. Fungus banyak digunakan pada kalangan penulis, ilustrator, animator dan perancang game, terutama penulis novel visual \& fiksi interaktif. Fungus bersifat open source yang bisa diakses oleh semua orang [7].

\section{H. Android}

Android adalah sebuah sistem operasi untuk perangkat mobile berbasis Linux yang mencakup sistem operasi, middleware, dan aplikasi. Android menyediakan platform terbuka bagi para pengembang untuk membuat aplikasi mereka sendiri [8].

\section{Use Case Diagram}

Use Case Diagram menjelaskan urutan kegiatan yang dilakukan aktor dan sistem untuk mencapai tujuan tertentu, menggambarkan fungsionalitas yang diharapkan dari sebuah sistem. Use Case Diagram juga mempresentasikan interaksi antar aktor atau pelaku dengan sistem [9].

\section{J. Activity Diagram}

Activity Diagram adalah representasi grafis dari seluruh tahapan alur kerja. Diagram ini mengandung aktivitas, pilihan tindakan, dan hasil dari aktivitas. Activity Diagram tidak menggambarkan behavior internal sebuah sistem dan interaksi antar subsistem secara pasti, tetapi lebih menggambarkan proses-proses dan jalur-jalur aktivitas dari level atas secara umum.

\section{K. Sequence Diagram}

Sequence diagram adalah salah satu diagram UML yang menggambarkan kolaborasi dinamis antara sejumlah objek. Fungsi dari diagram ini adalah menunjukkan rangkaian pesan yang dikirim antar objek dan juga interaksi antar objek.

\section{HCI (Human Computer Interaction)}

Interaksi manusia dan komputer merupakan suatu disiplin ilmu yang mengkaji tentang komunikasi atau interaksi di antara pengguna dengan sistem. Interaksi manusia komputer merupakan sekumpulan proses, dialog dan kegiatan dimana melaluinya pengguna memanfaatkan dan berinteraksi dengan komputer [10].

\section{Corel Draw X7}

CorelDraw adalah sebuah drawing software yang sangat populer. Sebuah software yang serba guna dan dimanfaatkan oleh para designer dari berbagai aliran seni murni, desain logo, desain ikon dan karakter, desain poster, brosur, kartu nama, cover buku, dan sebagainya [11].

\section{N. SPSS Statistics}

SPSS Statistics adalah aplikasi yang digunakan untuk melakukan analisis statistik. SPSS Statistics pertama kali muncul dengan versi PC dengan nama SPSS/PC+. Tetapi, dengan mulai populernya sistem operasi Windows. SPSS Statistics mulai mengeluarkan versi Windows (mulai dari versi 6.0 sampai versi terbaru sekarang) [12].

\section{HASIL PEMBAHASAN}

Sebelum dilakukan implementasi program, perlu dilakukan analisis dan desain sistem untuk mempermudah implementasi program karena sebagai acuan untuk menghasilkan program yang baik. 
A. Analisis Permasalahan

Berdasarkan latar belakang masalah pada penelitian ini dapat diidentifikasikan beberapa permasalahan berkurangnya minat baca anak. Ilmu pengetahuan dan teknologi berkembang dengan pesat, dimana media pembelajaran dengan menggunakan buku mulai ditinggalkan dan beralih menggunakan bentuk digital. Salah satu cara untuk menarik minat baca anak-anak yaitu dengan mengangkat cerita fabel dalam bentuk visual novel interaktif. Cerita fabel juga sering disebut cerita moral karena mengandung pesan yang berkaitan dengan moral, berkembangnya teknologi informasi memberikan dampak bagi cerita fabel itu sendiri. Visual novel termasuk salah satu jenis permainan yang difokuskan di bagian penceritaan, sehingga pemain seringkali seolaholah hanya membaca novel yang menampilkan gambar beserta teks dan suara. Dari permasalahan yang timbul di atas dapat ditarik kesimpulan pada penelitian ini untuk menarik minat baca anak dirancang dan dibuat aplikasi "Vino: Kelinci Dan Kura-Kura" untuk dapat mengatasi permasalahan tersebut.

\section{B. Desain Sistem}

Dalam pembuatan sebuah sistem, dibutuhkan pemahaman dasar mengenai rancangan dan alur kerja sistem. Pemahaman yang tepat akan mempermudah pembuatan sistem untuk setiap bagian yang akan dibuat. Setiap bagian yang akan dibuat harus terlebih dahulu dianalisis dan dirancang untuk menghasilkan informasi perancangan sistem yang jelas sehingga tidak mengalami kesulitan pada tahap implementasi.

\section{Flowchart Fungus}

Flowchart fungus digunakan untuk mempermudah pembuatan alur cerita pada pembuatan aplikasi "Vino:
Kelinci Dan Kura-Kura. Berikut ini adalah gambaran garis besar flowchart fungus dari aplikasi, seperti pada Gambar 1.

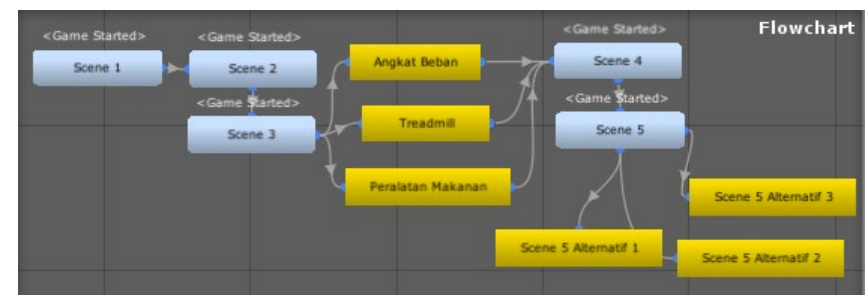

Gambar 1. Flowchart Fungus

Pada Gambar 1 dijelaskan bahwa alur cerita yang terdapat pada aplikasi "Vino: Kelinci Dan Kura-Kura" dibuat dengan menggunakan flowchart fungus untuk memudahkan pembuatan alur cerita yang berkesinambungan. Pada awal permainan pemain diharuskan untuk memainkan scene 1, scene 2, dan waktu berada pada scene 3 pemain diharuskan untuk memainkan interaksi yang terdapat pada scene tersebut yaitu terdiri dari angkat beban, treadmill, dan peralatan makanan. Ketika pemain berhasil melakukan 3 interaksi tersebut maka pemain dapat melanjutkan scene 4 dan ketika pemain berada pada scene 5 pemain diharuskan untuk memilih interaksi yang terdapat pada scene tersebut, untuk menentukan akhir cerita berdasarkan alternatif yang telah dibuat.

\section{Use Case Diagram}

Use case diagram menjelaskan urutan aktivitas yang dilakukan oleh aktor atau pelaku dan sistem untuk mencapai tujuan tertentu, menggambarkan fungsionalitas yang diharapkan dari sebuah sistem, serta mempresentasikan interaksi antar aktor atau pelaku dengan sistem.

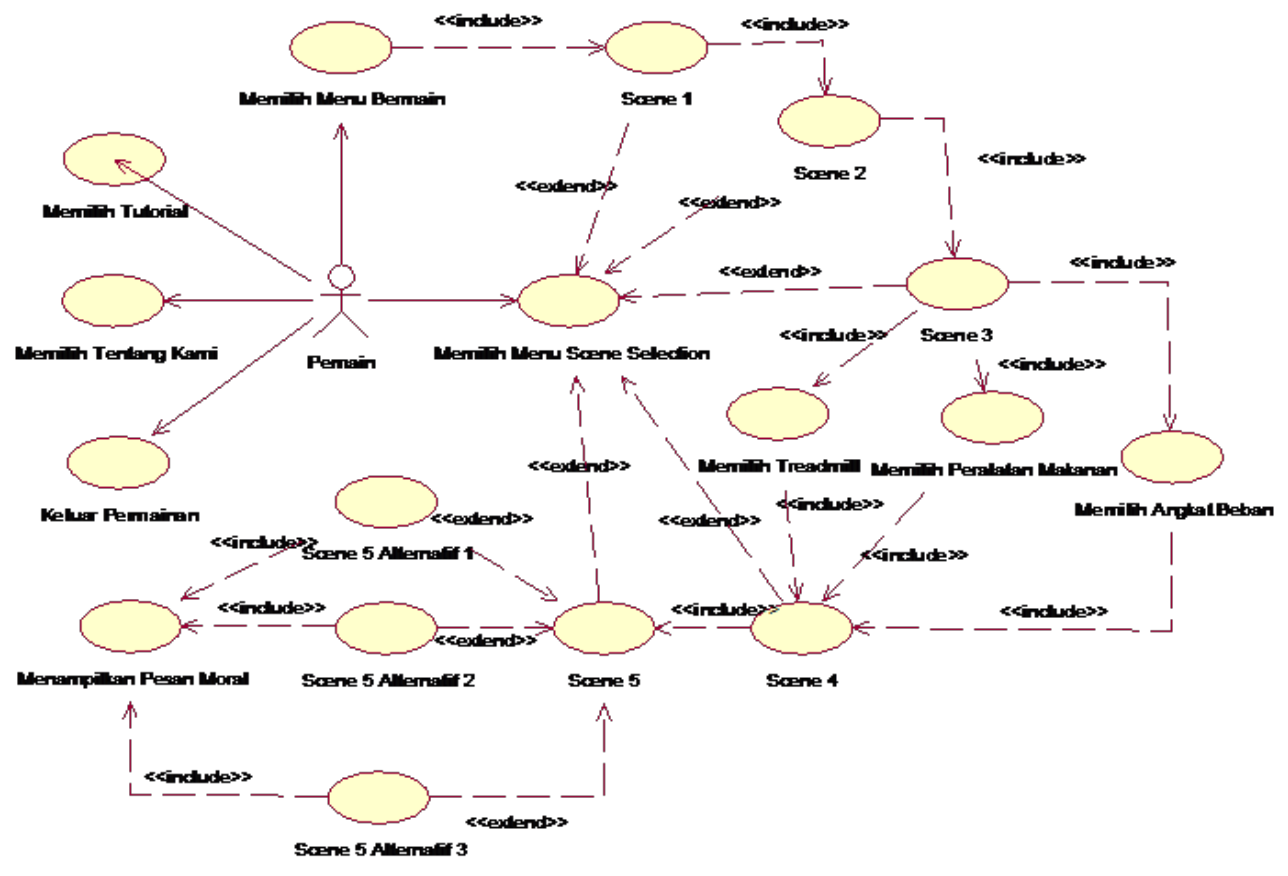

Gambar 2. Use Case Diagram Aplikasi "Vino: Kelinci Dan Kura-Kura" 
Pada Gambar 2 terlihat bahwa aplikasi ini hanya terdapat satu aktor, yaitu aktor pemain. Pemain dapat memilih menu bermain untuk dapat memulai permainan. Pada menu bermain pemain memainkan permainan sesuai dengan alur cerita yang dibuat, alur cerita yang dibuat ini terbagi oleh scene 1, scene 2, scene 3, scene 4, dan scene 5.

\section{E. Activity Diagram}

Activity diagram menggambarkan rangkaian aliran dari aktivitas, digunakan untuk mendeskripsikan aktivitas yang terbentuk dalam suatu operasi.. Berikut ini adalah activity diagram dari aplikasi "Visual Novel Interaktif Cerita Fabel Kelinci Dan Kura-Kura Pada Smartphone Berbasis Android Dengan Memanfaatkan Framework Fungus" yang akan dibuat.

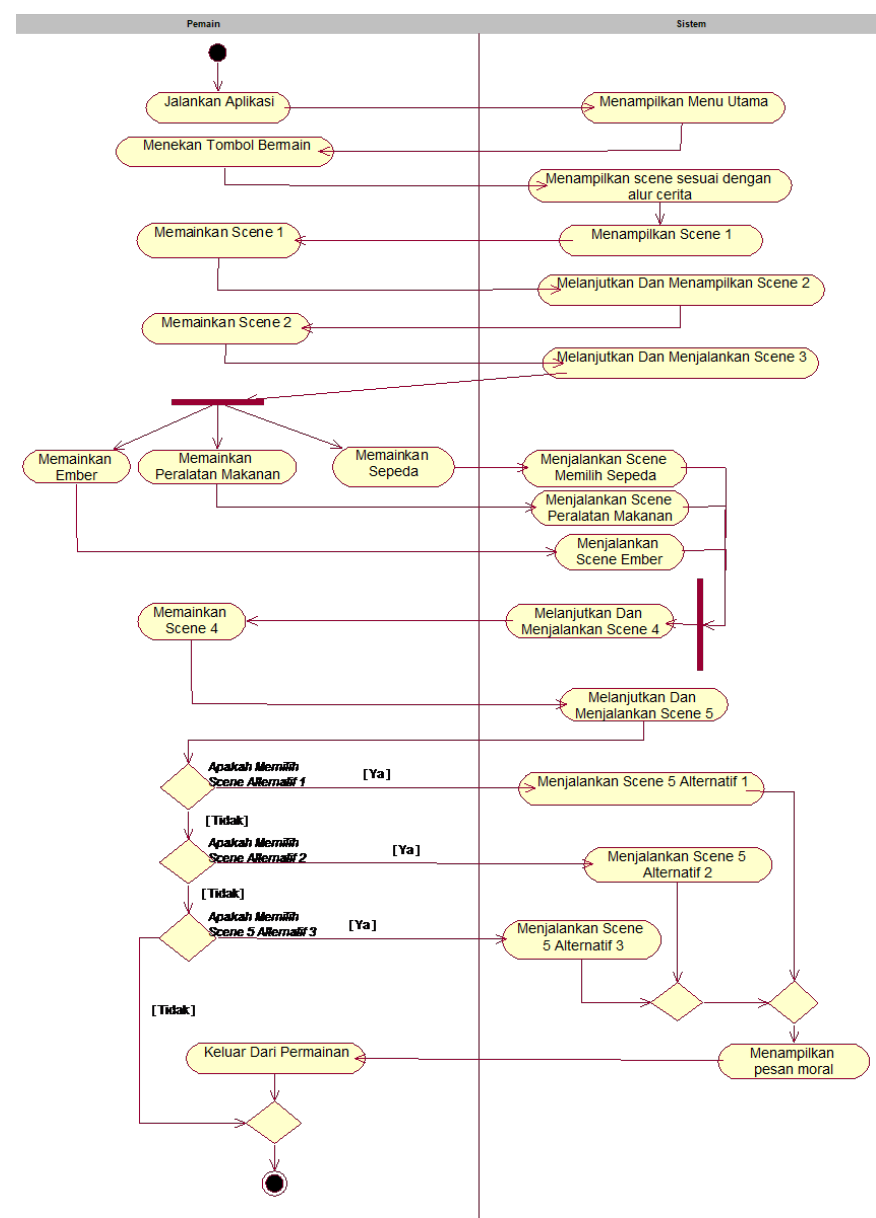

Gambar 3. Activity Diagram Permainan "Vino: Kelinci Dan Kura-Kura"

Pada Gambar 3 aktivitas yang dilakukan oleh pemain untuk dapat memainkan aplikasi yang telah dibuat sesuai dengan alur cerita.

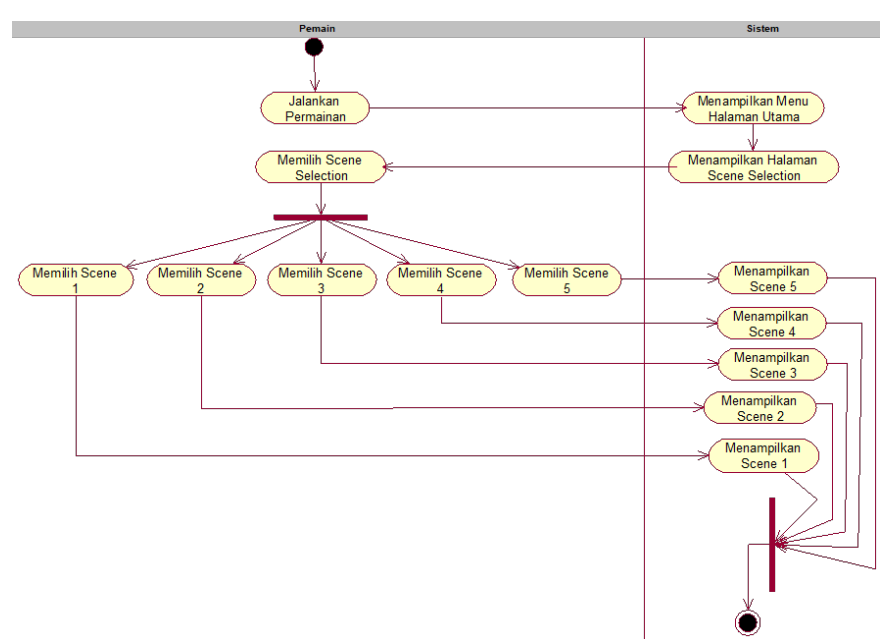

Gambar 4. Activity Diagram Memilih Menu Scene Selection

Pada Gambar 4 aktivitas yang dilakukan oleh pemain untuk dapat memilih scene yang diinginkan, untuk memilih scene yang diinginkan pemain harus memainkan scene terlebih dahulu dalam menu bermain.

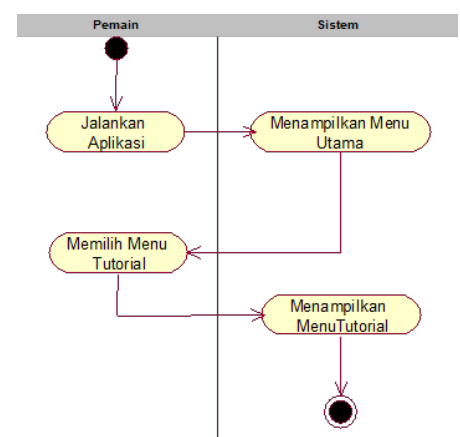

Gambar 5. Activity Diagram Memilih Menu Tutorial

Pada Gambar 5 aktivitas yang dilakukan oleh pemain untuk dapat melihat bagaimana cara bermain aplikasi tersebut. Untuk melakukan tutorial pemain menekan tombol menu tutorial.

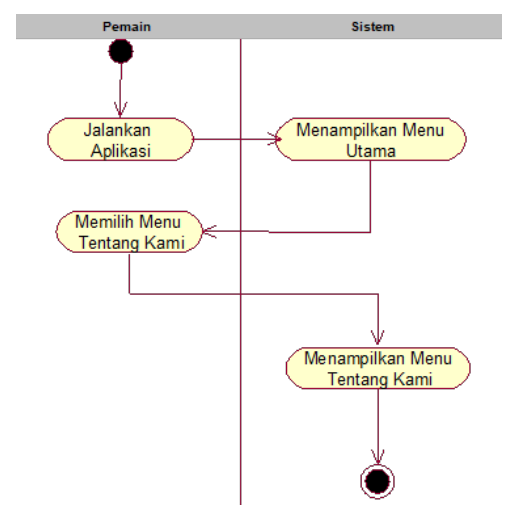

Gambar 6. Activity Diagram Memilih Menu Tentang Kami

Pada Gambar 6 aktivitas yang dilakukan oleh pemain untuk dapat melihat detail informasi dari aplikasi tersebut. 
Untuk memilih menu tentang kami pemain harus berada pada menu utama dan pemain menekan ikon tentang kami.

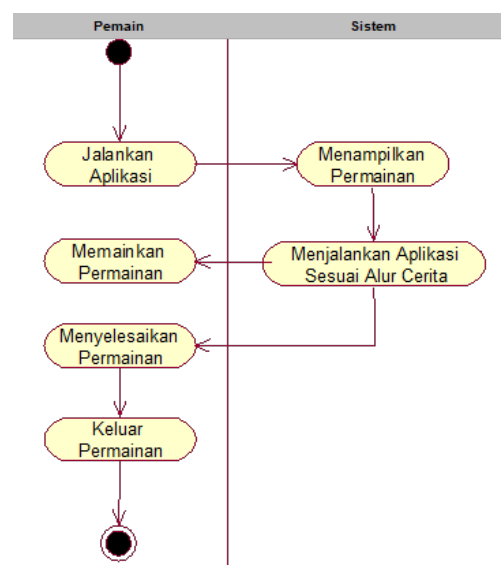

Gambar 7. Activity Diagram Memilih Keluar Permainan

Pada Gambar 7 aktivitas yang dilakukan oleh pemain untuk dapat keluar dari aplikasi tersebut, untuk memilih keluar permainan pemain menekan ikon keluar permainan.

\section{F. Sequence Diagram}

Sequence diagram merupakan gambaran interaksi antar masing-masing obyek pada setiap use case dalam urutan waktu. Pada sequence diagram yang dibuat berdasarkan aktor yang terlibat di dalam sistem dan dari aktor tersebut akan dibagi lagi berdasarkan use case yang terdapat pada aktor.

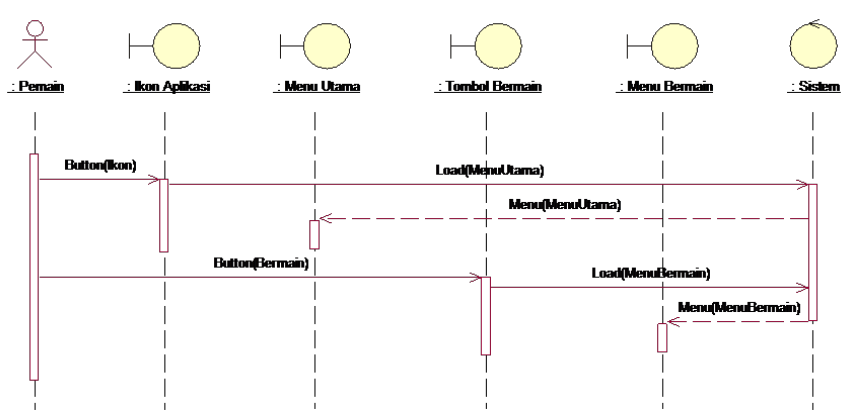

Gambar 8. Sequence Diagram Memilih Menu Bermain

Pada Gambar 8 sequence diagram memilih menu bermain menunjukkan proses yang dilakukan oleh pemain untuk memilih menu bermain. Proses memilih menu bermain menampilkan scene secara keseluruhan sesuai dengan alur cerita.

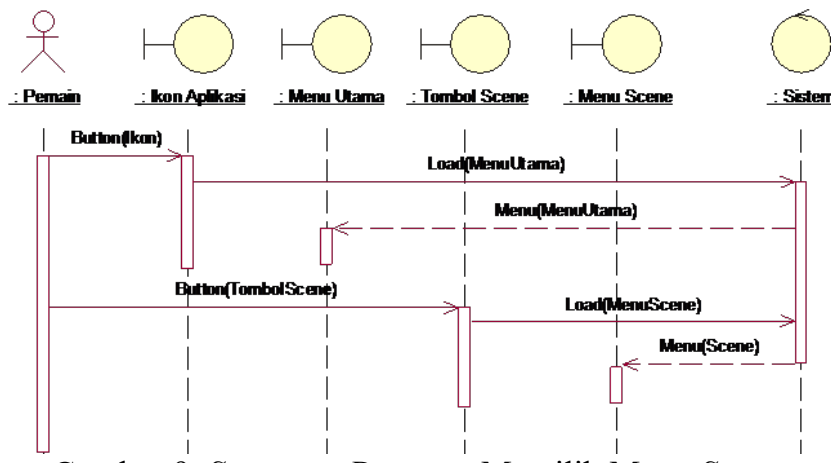

Gambar 9. Sequence Diagram Memilih Menu Scene Selection

Pada Gambar 9 sequence diagram memilih menu scene selection menunjukkan proses yang dilakukan oleh pemain untuk memilih menu scene selection. Proses memilih menu scene selection menampilkan scene secara keseluruhan dan pemain dapat memilih scene tersebut.

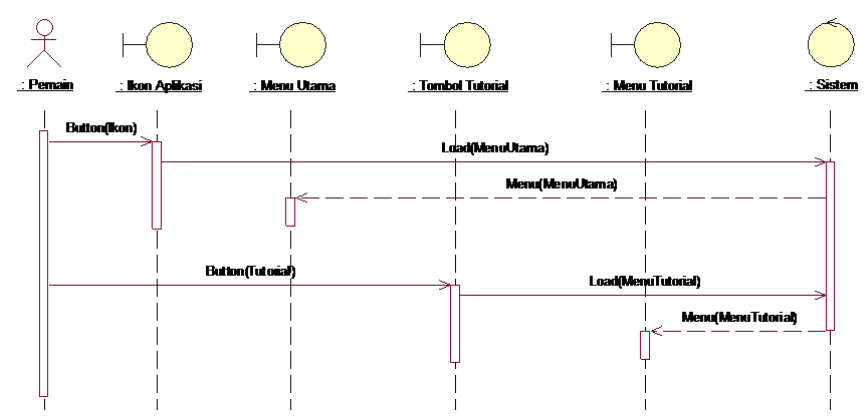

Gambar 10. Sequence Diagram Memilih Menu Tutorial

Pada Gambar 10 sequence diagram memilih menu scene selection menunjukkan proses yang dilakukan oleh pemain untuk memilih menu scene selection. Proses memilih menu scene selection menampilkan scene secara keseluruhan dan pemain dapat memilih scene tersebut.

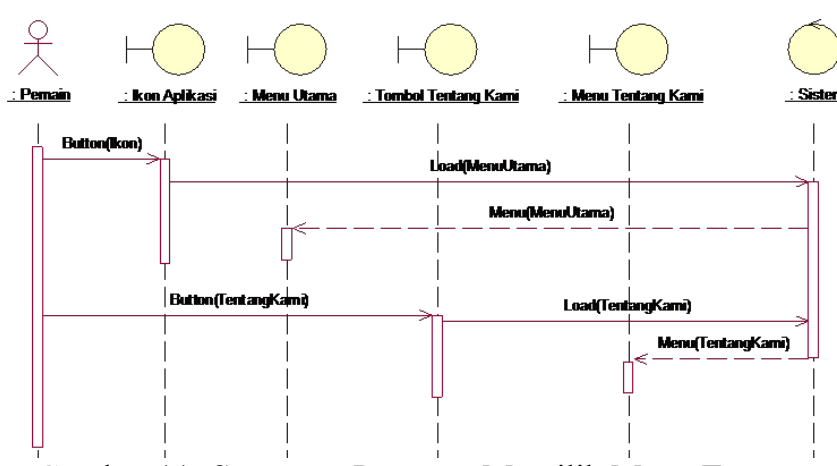

Gambar 11. Sequence Diagram Memilih Menu Tentang Kami

Pada Gambar 11 sequence diagram memilih menu tentang kami menunjukkan proses yang dilakukan oleh pemain untuk memilih menu tentang kami. Proses memilih menu tentang kami menampilkan detail informasi aplikasi tersebut. 


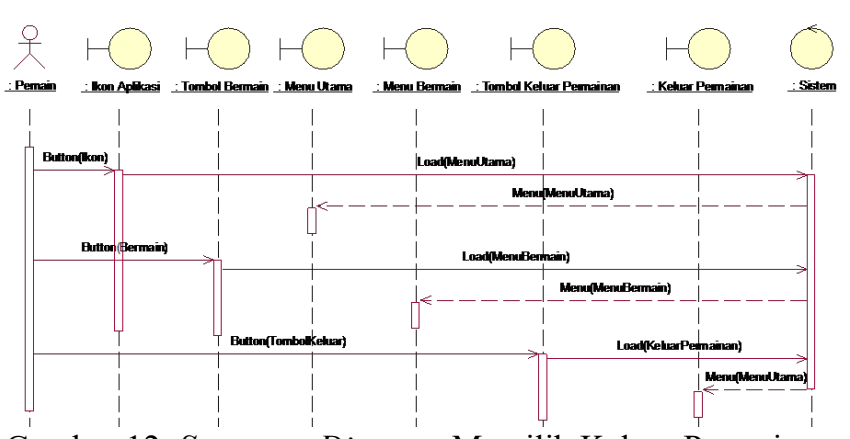

Gambar 12. Sequence Diagram Memilih Keluar Permainan

Pada Gambar 12 Sequence diagram memilih keluar permainan menunjukkan proses yang dilakukan oleh pemain untuk keluar dari aplikasi "Vino: Kelinci Dan Kura-Kura".

\section{G. Rancangan Input}

Aplikasi "Visual Novel Interaktif Cerita Fabel Kelinci Dan Kura-Kura Pada Smartphone Berbasis Android Dengan Memanfaatkan Framework Fungus" memiliki fitur yang dapat digunakan yaitu touch screen, drag, dan swipe screen dari perangkat Android. Dengan touch screen pemain dapat memilih kemampuan yang diwakili fitur touch dan swipe. Fitur touch screen digunakan untuk menekan layar smartphone, fitur drag screen digunakan untuk menekan layar dan menggesernya, sedangkan fitur swipe screen digunakan untuk menekan layar dan membuat gesture.

\section{H. Rancangan Output}

Rancangan Output merupakan tampilan yang dihasilkan oleh aplikasi "Visual Novel Interaktif Cerita Fabel Kelinci Dan Kura-Kura Pada Smartphone Berbasis Android" gambar yang divisualisasikan dibuat dengan program CorelDrawX7. Gambar yang telah dibuat memiliki referensi dari beberapa website yaitu 123rf, freepik, dan freevector.

\section{Desain Arsitektural}

Pada desain arsitektural ini akan dijelaskan mengenai alur kerja dari aplikasi yang dibuat. Alur kerja ini berisi semua interaksi yang ada pada aplikasi antara pemain, smartphone digunakan untuk menampilkan aplikasi. Secara garis besar, alur sistem aplikasi dapat dilihat Gambar 13.

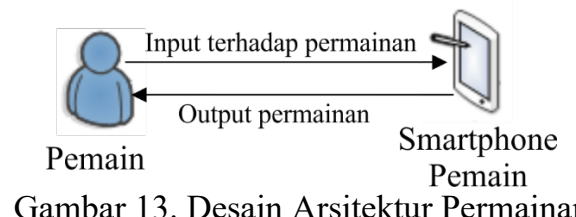

Pemain merupakan pihak utama dalam memainkan aplikasi ini dimana perangkat utama yang digunakan adalah smartphone. Smartphone digunakan untuk menjalankan aplikasi ini pemain dapat menjalankan fitur drag, swipe screen, dan touch screen.
J. Desain Prosedural

Desain prosedural perlu dibuat untuk menetapkan detail algoritma yang akan dinyatakan dalam aplikasi ini. Desain prosedural dibuat setelah menyelesaikan desain sistem, desain arsitektural, dan desain rancangan antarmuka.

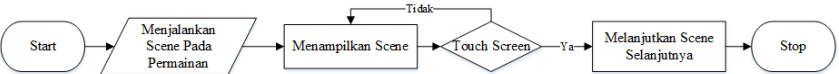

Gambar 14. Diagram Alir Proses Interaksi Touch Screen

Pada Gambar 14 proses ini dimulai ketika pemain memilih memainkan scene, maka pada layar smartphone terdapat objek yang bisa dilakukan untuk berinteraksi yaitu dengan cara melakukan touch pada objek scene. Interaksi tersebut digunakan untuk melanjutkan cerita selanjutnya atau melanjutkan scene selanjutnya.

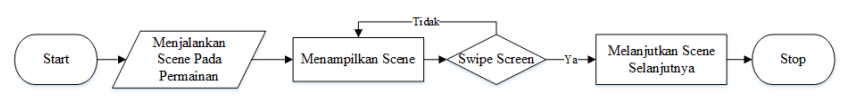

Gambar 15. Diagram Alir Proses Interaksi Swipe Screen

Pada Gambar 15 proses ini dimulai ketika pemain memilih memainkan scene, maka pada layar smartphone terdapat objek yang bisa dilakukan untuk berinteraksi yaitu dengan cara melakukan swipe pada objek scene. Interaksi tersebut digunakan untuk melanjutkan cerita selanjutnya atau melanjutkan scene selanjutnya.

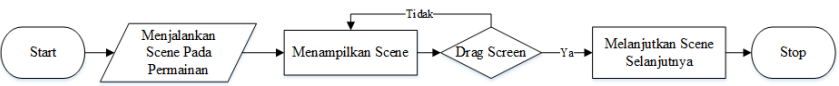

Gambar 16. Diagram Alir Proses Interaksi Drag Screen

Pada Gambar 16 proses ini dimulai ketika pemain memilih memainkan scene, maka pada layar smartphone terdapat objek yang bisa dilakukan untuk berinteraksi yaitu dengan cara melakukan drag pada objek scene. Interaksi tersebut digunakan untuk melanjutkan cerita selanjutnya atau melanjutkan scene selanjutnya.

\section{K. Desain Rancangan Antar Muka}

Pada sub bab ini akan ditunjukkan beberapa tampilan utama antar muka dari aplikasi "Vino: Kelinci Dan KuraKura" yang nantinya akan berinteraksi dengan pengguna.

\section{a) Menu Utama}

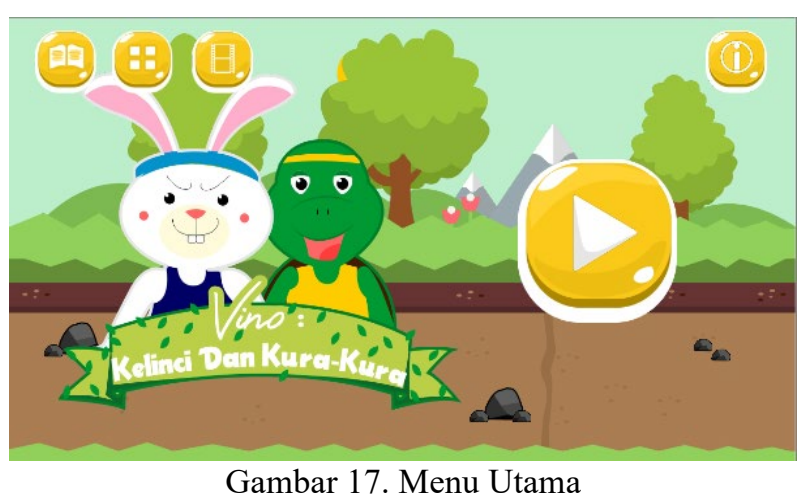

Gambar 17. Menu Utama 
Menu utama terdapat button yang terdiri dari button play, button scene selection yang digunakan untuk memilih scene yang diinginkan, button tutorial yang digunakan untuk melihat cara bermain aplikasi ini dan button galeri yang digunakan untuk melihat kumpulan gambar yang ada pada aplikasi ini.

b) Menu Tutorial

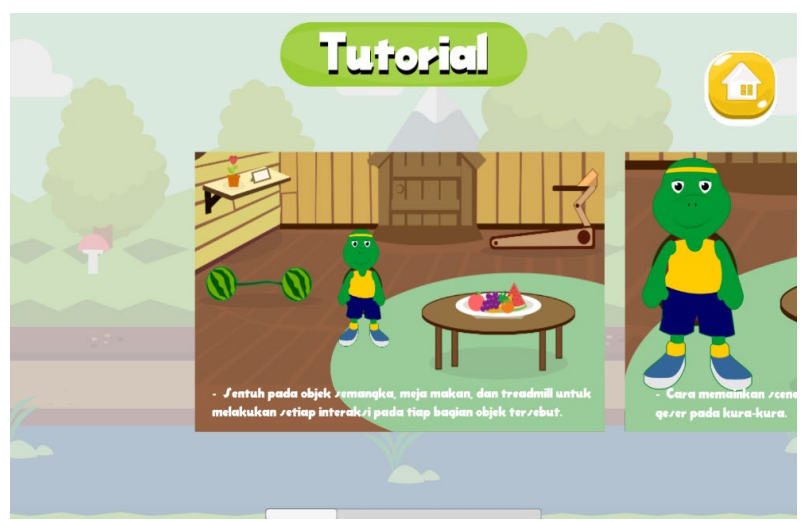

Gambar 18. Menu Tutorial

Menu tutorial terdapat keterangan cara bermain tiap scene pada aplikasi. Pada pojok atas sebelah kanan, terdapat button home yang berfungsi untuk menuju menu scene utama.

c) Menu Scene Selection

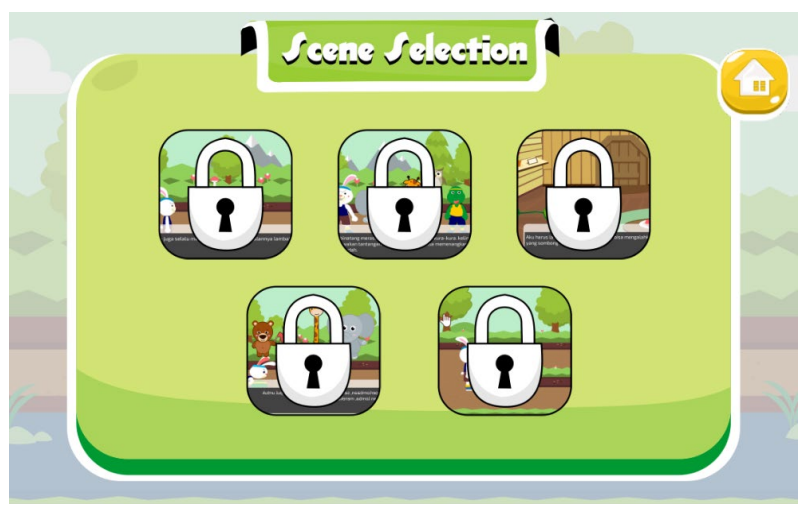

Gambar 19. Menu Scene Selection

Menu scene selection terdapat 5 scene yang digunakan sebagai scene utama dalam scene selection. Scene tersebut terbuka jika pemain dapat melewati atau memainkan scene yang ada pada aplikasi ini.

d) Menu Scene 1

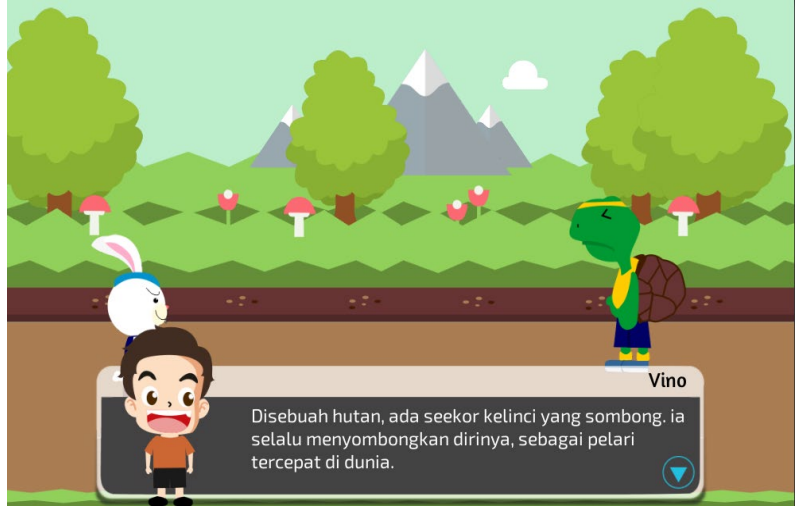

Gambar 20. Menu Scene 1

Menu scene 1 terdapat button yang terdiri dari button kembali dan button selanjutnya. Button kembali yang digunakan untuk beralih pada scene sebelumnya dan button selanjutnya yang digunakan untuk beralih pada scene selanjutnya pada aplikasi ini.

e) Menu Scene 2

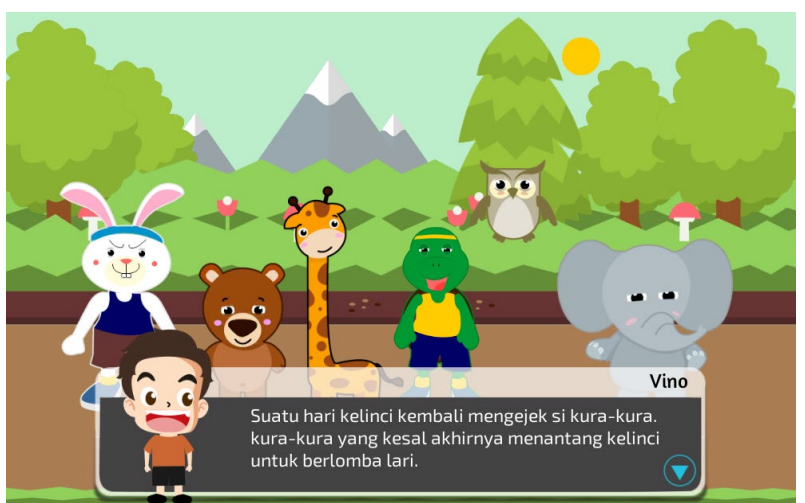

Gambar 21. Menu Scene 2

Menu scene 2 juga terdapat button yang terdiri dari button kembali dan button selanjutnya. Button kembali yang digunakan untuk beralih pada scene 1 dan button selanjutnya yang digunakan untuk beralih pada scene 3 pada aplikasi ini.

f) Menu Scene 3

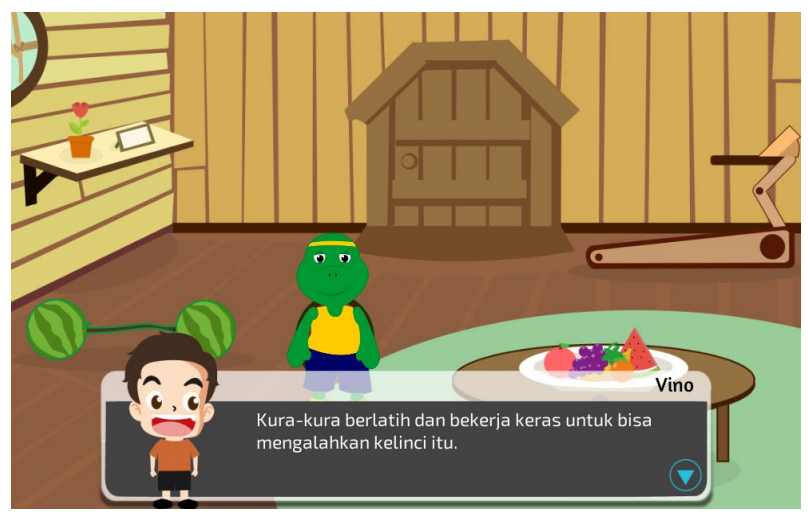

Gambar 22. Menu Scene 3 
Menu scene 3 juga terdapat button yang terdiri dari button kembali yang digunakan untuk beralih pada scene sebelumnya dan button selanjutnya yang digunakan untuk beralih pada scene selanjutnya pada aplikasi ini.

\section{g) Menu Scene 4}

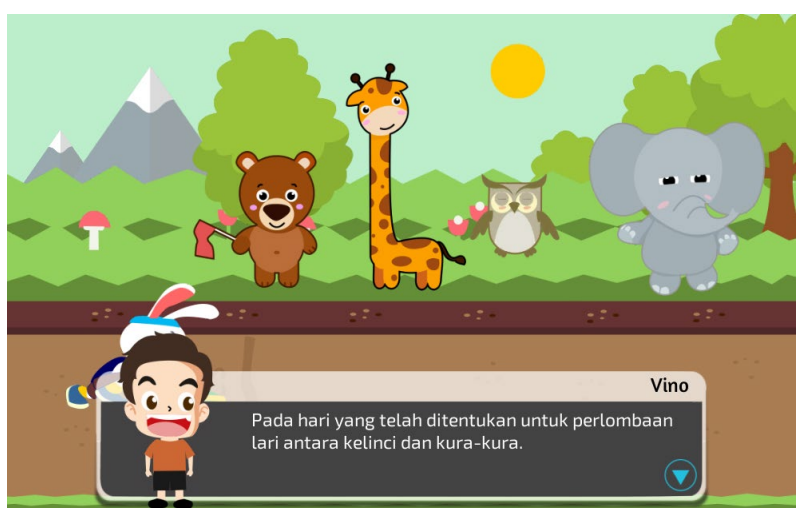

Gambar 23. Menu Scene 4

Menu scene 4 terdapat button yang terdiri dari button kembali yang digunakan untuk beralih pada scene sebelumnya dan button selanjutnya yang digunakan untuk beralih pada scene selanjutnya pada aplikasi ini.

h) Menu Scene 5

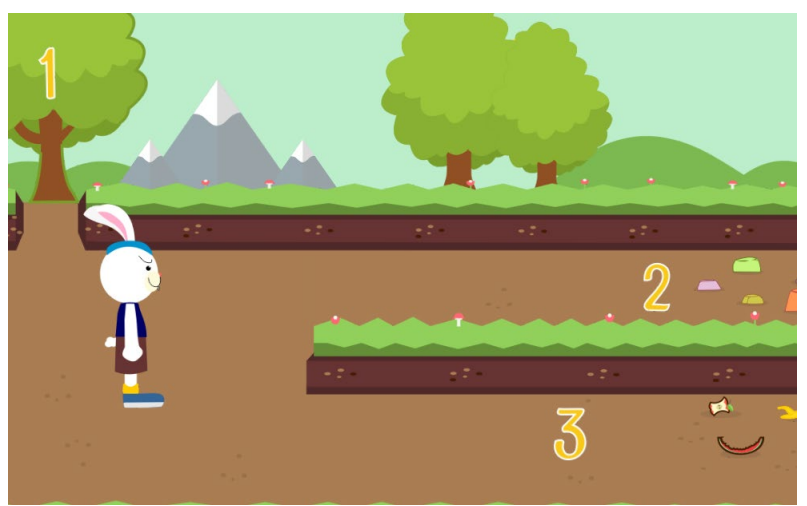

Gambar 24. Menu Scene 5

Menu scene 5 jika pemain memilih pohon maka jalan cerita alternatif 1 yang dipilih yaitu kura-kura yang memenangkan pertandingan tersebut atau normal ending, jika pemain memilih jalan 1 maka jalan cerita alternatif 2 yang dipilih yaitu kelinci yang memenangkan pertandingan atau bad ending dan jika pemain memilih jalan 2 maka jalan cerita alternatif 3 yang dipilih yaitu kelinci dan kura-kura yang memenangkan pertandingan atau perfect ending.

\section{Pengujian}

Uji coba yang dilakukan pada aplikasi "Vino: Kelinci Dan Kura-Kura" dilakukan menggunakan pengujian white box dan usability testing. White box testing merupakan salah satu cara untuk menguji suatu aplikasi dengan cara melihat modul untuk dapat meneliti dan menganalisis kode dari program yang dibuat terdapat kesalahan atau tidak. Jika modul yang dihasilkan berupa output tidak sesuai dengan yang diharapkan, maka akan di-compile ulang dan diperiksa kembali kode-kode tersebut hingga sesuai dengan yang diharapkan. Usability testing merupakan pengujian yang dilakukan untuk menguji pengguna apakah dapat berinteraksi dengan aplikasi yang dibuat.

Hasil uji coba white box testing dengan menggunakan metode basis path menunjukkan bahwa aplikasi dapat berjalan dengan baik. Hal tersebut dibuktikan pada saat penulis melakukan uji coba terhadap jalur independen yang dihasilkan. Pengujian hasil uji coba usability testing dengan menggunakan metode problem discovery dengan menggunakan skenario berdasarkan 5 kriteria yaitu waktu, sikap, perulangan, visual, dan interaksi. Menunjukkan bahwa aplikasi "Vino: Kelinci Dan Kura-Kura" dapat menarik minat baca anak usia 4 sampai 7 tahun. Hal tersebut dibuktikan 10 dari 10 responden mengulang lebih dari 1 kali ketika menggunakan aplikasi, dibandingkan dengan pada saat mereka membaca buku.

\section{KESIMPULAN}

Pada sub bab ini diperoleh beberapa kesimpulan dari hasil uji coba aplikasi "Vino: Kelinci Dan Kura-Kura" yang telah dilakukan. Kesimpulan yang dapat diambil antara lain: Aplikasi "Vino: Kelinci Dan Kura-Kura" dapat menumbuhkan minat baca bagi anak usia 4 sampai 7 tahun. Hal tersebut didasari oleh beberapa faktor yaitu Dengan mengangkat cerita fabel dalam bentuk visual novel interaktif, menjadikan penyampaian dan tampilan aplikasi "Vino: Kelinci Dan Kura-Kura" lebih menarik bagi anak-anak usia 4 sampai dengan 7 tahun. Pada aplikasi "Vino: Kelinci Dan Kura-Kura" terdapat 3 bagian akhir cerita yang berbeda-beda yaitu normal ending, bad ending, dan perfect ending. Tiga bagian akhir cerita tersebut membuat aplikasi menjadi menarik sehingga pemain tidak jenuh saat memainkan aplikasi. Hasil uji coba usability testing dengan menggunakan metode problem discovery berdasarkan kriteria perulangan menunjukkan 10 dari 10 responden mengulang lebih dari 1 kali ketika menggunakan aplikasi, dibandingkan dengan pada saat mereka membaca buku.

Aplikasi "Vino: Kelinci Dan Kura-Kura" dapat berjalan dengan baik, hal ini dapat dibuktikan dari hasil uji coba white box dengan menggunakan metode basis path. Penggunaan kombinasi Unity 3D dengan framework fungus dapat mempermudah pembuatan aplikasi visual novel interaktif berbasis Android. Terutama dalam membuat dan menampilkan dialog serta jalan cerita yang beragam.

\section{REFERENSI}

[1] Azhar, A. (2013). Media Pembelajaran. Jakarta: PT Rineka Cipta.

[2] Comobe Corp Designer. (2015). 150 Teknik Profesional. Jakarta: PT Elex Media Komputer. 
[3] Ernes, S. (2015). 50 Cerita Fabel Dunia: YunaniSpanyol-Australia-Afrika-Indonesia. Jakarta: AnakKita.

[4] Hart, J. (2013). The Art of the Storyboard: A Filmakers's Introduction. USA: Taylor \& Francis.

[5] Okita, A. (2015). Learning C\# Programming With Unity $3 D$. New York: CRC Press.

[6] Smith, M. (2015). Unity 5.x Cookbook. UK: Packt Publishing Ltd.

[7] DaGraça, M. (2017). Learning C\# 7 By Developing Games With Unity 2017: Learn C\# Programming By Building Fun And Interactive Games With Unity. UK: Packt Publishing Ltd.
[8] Wahana Komputer. (2014). Membuat Aplikasi Android untuk Tablet \& Handphone. Jakarta: PT Elex Media Komputindo.

[9] Shalahuddin, M. \& Rosa, A.S. (2015). Rekayasa Perangkat Lunak Terstruktur dan Berorientasi Objek. Bandung: Informatika.

[10] Meena, K \& Sivakumar, R. (2015). Human Computer Interaction. Delhi: PHI Learning Pvt. Ltd.

[11] Wibawanto, W. (2017). Desain dan Pemrograman Multimedia Pembelajaran Interaktif. Jember: Cerdas Ulet Kreatif Publisher.

[12] Santoso, S. (2018). Menguasai Statistik Dengan SPSS 25. Jakarta: PT Elex Media Komputindo. 